\title{
Influence of High Tunnel Production and Planting Date on Yield, Growth, and Early Blight Development on Organically Grown Heirloom and Hybrid Tomato
}

\author{
Mary A. Rogers and Annette L. Wszelaki ${ }^{1}$
}

ADDITIONAL INDEX WORDs. hoop house, protected agriculture, season extension, Solanum lycopersicum, Alternaria solani

SUMMARY. High tunnels are rapidly gaining favor from growers in many regions of the United States because these structures extend the growing season and increase quality of high-value horticultural crops. Small to midsized organic growers who sell tomatoes (Solanum lycopersicum) for the fresh market can benefit from lower disease pressure and higher marketable yields that can be achieved in high tunnels. High tunnels also protect crops from environmental damage and benefit production of heirloom tomatoes as these varieties often have softer fruit and are more susceptible to diseases and cracking and splitting than hybrid varieties. The objective of this study was to determine the impacts of high tunnel production and planting date on heirloom and hybrid tomato varieties by observing differences in plant growth, yield, marketability, and early blight (Alternaria solani) development within an organic production system. This study showed no increase in total yields in high tunnels as compared with the open field, but increased marketability and size of tomatoes, and lowered incidence of defoliation resulting from early blight. Tomato planted earlier in both high tunnels and the open field yielded more marketable fruit during the production season than plants established on later planting dates. Hybrid varieties yielded more marketable fruit than heirloom varieties; however, heirloom tomatoes can have equivalent market value because of greater consumer demand and premium prices attained in the local market.

$\mathrm{H}$ igh tunnels are unheated season extension structures that allow growers in temperate regions to fulfill consumer demand for fresh market produce at times which are traditionally off-season (Conner et al., 2009). High tunnel production is well suited to high-value crops, such as tomato, bell pepper (Capsicum annuum), garlic (Allium sativum), strawberry (Fragaria ×ananassa), blackberry and raspberry (Rubus species and varieties), and multiple species of cut flowers (Lamont et al., 2003; Orzolek et al., 2002). As year-round consumer demand for fresh, locally grown, and organic produce continues

Department of Plant Sciences, University of Tennessee, 252 Ellington Plant Sciences Building, 2431 Joe Johnson Drive, Knoxville, TN 37996

We thank Bobby Simpson, Lee Ellis, Bill Lively, and Bobby Terry of the East Tennessee Research and Education Center for field support. Additionally, we thank Sarah Broughton, Josh Cantrell, Kelly Corum, Bobby Evans, Phil Flanagan, Nora Hutchison, Mechelle Kneidinger, Jeff Martin, Grant McCarty, Alex Mindermann, DJ Mitchell, Philip Moore, Daniel Priddy, Mary Clare Smith, and Alexandra Spaulding for technical support. We are grateful to Bill Klingeman and David Butler for their thorough review of the manuscript.

${ }^{1}$ Corresponding author. E-mail: annettew@utk.edu. to increase, more farmers markets and other direct marketing avenues are on the rise (Zepeda and Deal, 2009), creating opportunities for growers to adopt and benefit from high tunnel production.

Few production-based studies have evaluated the effect of high tunnels within an organic farming framework. High tunnel production systems are well suited to organic farming as tunnels are energy efficient and can improve the quality and yield of vegetables over field-grown systems (Lamont et al., 2003; Wittwer and Castilla, 1995). Many small-scale organic growers market locally and high tunnels can provide season extension and allow growers to capitalize on higher quality heirloom varieties that are in demand and would otherwise not be available in a long-distance distribution system. Organic growers have fewer pest management options than conventional growers and high tunnels can aid in pest control. High tunnels were shown to increase yield of organically grown tomato plants that received compost applications by reducing disease incidence and development of early blight (Baysal et al., 2009). From a quality standpoint, phytonutrient studies have shown differences in nutrient uptake in vegetables grown in high tunnels vs. open field plots and receiving organicbased vs. conventional fertilizers (Gent, 2002; Zhao et al., 2007).

Tomato is a high-value crop well adapted to the high tunnel system, where economic return can be higher compared with field-grown crops (Orzolek et al., 2002). In addition to earlier harvests, protected agriculture systems, like high tunnels, can increase fruit quality by reducing wind damage and injury from insects, diseases, birds, and rodents. Protected systems also provide crops with an indeterminate growth habit with a longer harvest season as compared with field production (Wittwer and Castilla, 1995).

Organically grown heirloom tomatoes provide a potentially lucrative niche as a segment of the overall freshmarket tomato sector. Many openpollinated, heirloom tomato varieties have an indeterminate growth habit, simultaneously producing new vegetative growth and fruit over time, in contrast to determinate varieties that produce the majority of fruit within a discrete time period. Heirloom tomato varieties are growing in popularity and consumers will pay premiums above the cost of conventional hybrid fruit (Jordan, 2007). However, heirloom varieties can be challenging to

\begin{tabular}{llll}
\hline $\begin{array}{l}\text { Units } \\
\begin{array}{l}\text { To convert U.S. to SI, } \\
\text { multiply by }\end{array}\end{array}$ & U.S. unit & SI unit & $\begin{array}{l}\text { To convert SI to U.S., } \\
\text { multiply by }\end{array}$ \\
\hline 0.3048 & $\mathrm{ft}$ & $\mathrm{m}$ & 3.2808 \\
3.7854 & gal & $\mathrm{L}$ & 0.2642 \\
2.54 & inch(es) & $\mathrm{cm}$ & 0.3937 \\
25.4 & inch $(\mathrm{es})$ & $\mathrm{mm}$ & 0.0394 \\
0.4536 & $\mathrm{lb}$ & $\mathrm{kg}$ & 2.2046 \\
1.1209 & $\mathrm{lb} / \mathrm{acre}$ & $\mathrm{kg} \cdot \mathrm{ha}^{-1}$ & 0.8922 \\
0.0254 & $\mathrm{mil}$ & $\mathrm{mm}$ & 39.3701 \\
6.8948 & $\mathrm{psi}$ & $\mathrm{kPa}$ & 0.1450 \\
$\left({ }^{\circ} \mathrm{F}-32\right) \div 1.8$ & ${ }^{\circ} \mathrm{F}$ & ${ }^{\circ} \mathrm{C}$ & $\left(1.8 \times{ }^{\circ} \mathrm{C}\right)+32$
\end{tabular}


produce because they tend to be physically inconsistent in growth and form and prone to bruising, splitting, and cracking; thus, their distribution is often limited to local fresh markets (Vavrina et al., 1997). High tunnel production can reduce splitting and cracking in heirloom tomatoes, thus improving quality.

In regard to the causes of fruit splitting or cracking, one common contributor is rapid water uptake that results in increased turgor pressure within the fruit, initiating cracks or splits (Dorais et al., 2004). In a high tunnel system, cracking can be reduced by scheduled drip irrigation, rather than contending with natural rain events in the open field. Direct sunlight exposure can also cause cracking (Emmons and Scott, 1997). High tunnels reduce direct exposure from the sun and reduce foliage loss because of diseases. High tunnels create a microclimate that impacts abiotic and biotic factors and influences plant growth and development. Minimized fluctuations in day and night temperatures, increased soil temperature, elevated carbon dioxide $\left(\mathrm{CO}_{2}\right)$ levels, and changes in soil moisture and spectral light quality are environmental conditions associated with tunnel production (Millner et al., 2009; Wittwer and Castilla, 1995). Increasing soil and air temperatures and $\mathrm{CO}_{2}$ levels hasten plant growth and maturation, especially in plants with an indeterminate growth habit, and influence yield quality (Morrison and Lawlor, 1999). Simultaneously, these changes impact plant disease incidence within the high tunnel system.

High tunnel coverings affect the quality of light reaching the foliage. Plastic coverings that absorb ultraviolet light at $340 \mathrm{~nm}$ can reduce the incidence and severity of some diseases, including gray mold (Botrytis sp.), white mold (Sclerotinia sclerotiorum), and leaf mold (Fulvia fulva) by inhibiting sporulation (Gullino et al., 1999). Furthermore, plastic coverings may increase the amount of ultraviolet B (medium wave) radiation reaching the plants, inducing chromosomal changes that affect production of secondary metabolites and plant chemistry that can translate to increased systemic resistance to plant pathogens (Raviv and Antignus, 2004).

High tunnels also reduce foliar pathogens by limiting spore dispersal via water. Early blight is a persistent, economically important foliar disease of tomato causing premature defoliation and reducing the photosynthetic ability of infected plants. Development of early blight is increased by leaf wetness, inoculum density, and age of the plant; host plant susceptibility also varies by variety (Vloutoglou and Kalogerakis, 2000). High tunnel systems provide shelter from rain and soil splashing, thus may decrease early blight severity by keeping the foliage clean and dry. Additionally, planting date can also influence disease development. Plant diseases caused by anthracnose (Colletotrichum sp.), early blight, southern blight (Sclerotium rolfsii), and septoria leaf spot (Septoria lycopersici) were more severe among early planted tomato than late planted field-grown tomato, regardless of fungicide treatment (Kennedy et al., 1983). High tunnels can mitigate these challenges by regulating temperature and moisture and may help reduce disease pressure.

The objective of this study was to determine the impacts of high tunnel production and planting date on heirloom and hybrid tomato varieties by observing differences in plant growth, yield, marketability, and early blight development within an organic production system.

Table 1. Planting dates, harvest dates, peak harvest and harvest window from three different planting dates of organically grown tomato plants in 2009 and 2010 at the University of Tennessee Organic Crops Unit in Knoxville, TN.

\begin{tabular}{|c|c|c|c|c|c|c|}
\hline & & 2009 & & & 2010 & \\
\hline \multirow{14}{*}{$\begin{array}{l}\text { Planting date } \\
\text { Harvest date }\end{array}$} & 27 Mar. & 17 Apr. & 8 May & 25 Mar. & 16 Apr. & 7 May \\
\hline & 24 June & 9 July & 16 July & 17 June & 25 June & 15 July \\
\hline & 28 June & 13 July & 20 July & 21 June & 28 June & 19 July \\
\hline & 2 July & 16 July & 23 July & 23 June & I July & 22 July \\
\hline & 6 July & 20 July & 27 July & 25 June & 6 July & 29 July \\
\hline & 9 July & 23 July & 3 Aug. & 28 June & 8 July & 2 Aug. \\
\hline & 13 July & 27 July & 6 Aug. & I July & 12 July & 5 Aug. \\
\hline & 16 July & 3 Aug. & 8 Aug. & 6 July & 15 July & 9 Aug. \\
\hline & 20 July & 6 Aug. & & 8 July & 19 July & \\
\hline & 23 July & 8 Aug. & & 12 July & 22 July & \\
\hline & 27 July & & & 15 July & 29 July & \\
\hline & 3 Aug. & & & 19 July & 2 Aug. & \\
\hline & 6 Aug. & & & 22 July & 5 Aug. & \\
\hline & 8 Aug. & & & $\begin{array}{r}29 \text { July } \\
2 \text { Aug. } \\
5 \text { Aug. } \\
9 \text { Aug. }\end{array}$ & 9 Aug. & \\
\hline $\begin{array}{l}\text { Time from first to } \\
\text { last harvest (d) }\end{array}$ & 46 & 31 & 24 & 53 & 45 & 21 \\
\hline Peak harvest date & 16 July & 16 July & 27 July & 7 July & 13 July & 2 Aug. \\
\hline $\begin{array}{l}\text { Time after planting } \\
\text { to peak harvest (d) }\end{array}$ & 118 & 90 & 80 & 104 & 88 & 87 \\
\hline
\end{tabular}

\section{Materials and methods}

EXPERIMENTAL DESIGN AND MAINTENANCE. The experiment was a split-split plot design consisting of two production systems (main plot), three planting dates (sub-plot), and six tomato varieties (sub-sub-plot); each main plot had 18 sub-plots as the experimental units. The plots were replicated three times for each production system, planting date, and variety in 2009 and 2010 . The production systems were high tunnels and open field plots. Three high tunnels were constructed in Oct. 2008 at the Organic Crops Unit of the East Tennessee AgResearch and Education Center in Knoxville, TN (lat. $35.88^{\circ} \mathrm{N}$, long. $83.93^{\circ} \mathrm{W}$ ), measuring $35 \times 48 \mathrm{ft}$ with 14 -ft-high gothic arches (Griffin Greenhouse, Knoxville, $\mathrm{TN}$ ), fitted with a double layer (not inflated) of 6-mil greenhouse grade, ultraviolet-treated polyethylene plastic and 6-ft roll-up sides. Polycarbonate sliding doors were installed on either end of the tunnels, allowing entry for a small tractor. Open field plots were the same dimensions as the high tunnels $(35 \times 48 \mathrm{ft})$ and located $30 \mathrm{ft}$ to the southwest of the tunnels. The parcel of land containing the high tunnel and open field plots was not certified organic, but was managed using organic 
amendments for two years before the start of the experiment.

Before planting, soil in the main plots was rototilled to a depth of 6 inches with a rotary tiller (Bush Hog, Selma, AL) pulled by a compact tractor (B Series; Kubota Tractor Corp., Torrance, CA). Composted mushroom substrate $(2 \mathrm{~N}-0.4 \mathrm{P}-1.7 \mathrm{~K}$; Monterey Mushroom, Loudon, TN) was applied at the rate of $1200 \mathrm{lb}$ to each area $(31,114 \mathrm{lb} /$ acre $)$, estimated to deliver $124 \mathrm{lb} /$ acre of available nitrogen $(\mathrm{N})$ the first year, assuming 20\% availability. Irrigation was established with drip tape (10 mil thick), emitting water every 12 inches and providing $13 \mathrm{gal} / \mathrm{h}$ of water at $8 \mathrm{psi}$ (Netafim, Tel Aviv, Israel). Soil moisture was assessed by feel and appearance, and irrigation was applied for $2 \mathrm{~h}$ per irrigation event based on the needs of individual rows. The drip tape was laid in six rows per main plot on 4.5 -ft centers, and black plastic mulch ( $3 \mathrm{ft}$ wide, 1 mil thick; Pliant Corp., Chippewa Falls, WI) was laid on top of the drip tape, with sides and ends of the plastic buried. Each planting date sub-plot consisted of two rows per main plot. In 2009, in-row spacing for tomato plants was $1.5 \mathrm{ft}$, with eight plants per sub-sub-plot, three sub-sub-plots per row. In 2010, spacing was increased to $2 \mathrm{ft}$, with six plants per sub-sub-plot to increase airflow and reduce disease potential and overcrowding of plants. Plot dimensions were the same for both years, $4.5 \times 12 \mathrm{ft}$. Because of different growth habits between the heirloom (indeterminate growth) and hybrid (determinate growth) varieties and their differing water demands, randomization was done within rows, with three rows devoted to heirlooms and three rows devoted to hybrids (one row per planting date in each main plot).

Six-week-old tomato seedlings were transplanted at three different planting dates: 27 Mar. (first planting), 17 April (second planting), and 8 May (third planting) in 2009; and 25 Mar. (first planting), 16 April (second planting), and 7 May (third planting) in 2010 (Table 1). Six varieties of tomato plants were used; three heirloom indeterminate types and three determinate hybrid types. The heirloom varieties were 'Arkansas Traveler', 'Cherokee Purple', and 'Valencia' (certified organic; Seeds of Change, Santa Fe, NM). The hybrid varieties were 'BHN 589' (untreated; Seedway, Elizabethtown, PA), 'Fletcher' (untreated, Seedway), and 'Primo Red' (treated; Harris Moran Seeds, Modesto, CA). Hybrid varieties were chosen because of Fusarium wilt (Fusarium oxysporum) and verticillium wilt ( Verticllium sp.) resistance. Tomato seeds were started in the greenhouse in 128cell plug trays using Sunshine Organic Grow Mix (Sun Gro, Bellevue, WA). Tomato transplants were fertilized weekly with diluted hydrolyzed, fish fertilizer (2N-1.8P-0.8K; Neptune's Harvest, Gloucester, MA) at the rate of $100 \mathrm{ppm} \mathrm{N}$ for the first 3 weeks and increasing to $200 \mathrm{ppm} \mathrm{N}$ for the last 3 weeks under $16 / 8 \mathrm{~h}$ (day/night). In the field, tomato plants were fertigated with 0.35 gal per week of liquid fish emulsion $(2.6 \mathrm{~N}-0.87 \mathrm{P}-0.22 \mathrm{~K}$;

Table 2. Plant height in 2009 and 2010 and complete and incomplete inflorescence number (2010 only) of six varieties of organically grown tomato plants over three planting dates in high tunnels and open-field plots at the University of Tennessee Organic Crops Unit in Knoxville, TN.

\begin{tabular}{|c|c|c|c|c|c|}
\hline \multirow{2}{*}{ Treatment } & & \multicolumn{2}{|c|}{ Plant ht $[\text { mean } \pm \text { SE }(\mathrm{cm})]^{\mathrm{z}}$} & \multirow{2}{*}{$\begin{array}{l}\text { Complete inflorescence } \\
{[\text { mean } \pm \text { SE }(\text { no. })]^{\mathrm{y}}}\end{array}$} & \multirow{2}{*}{$\begin{array}{c}\text { Incomplete inflorescence } \\
{[\text { mean } \pm S E(\text { no. })]^{\mathrm{y}}}\end{array}$} \\
\hline & & 2009 & 2010 & & \\
\hline \multicolumn{6}{|l|}{ Production system } \\
\hline High tunnel & & $79.3 \pm 2.1 \mathrm{a}^{\mathrm{x}}$ & $63.2 \pm 1.1 \mathrm{a}$ & $0.6 \pm 0.1 \mathrm{a}$ & $1.5 \pm 0.1 \mathrm{a}$ \\
\hline Open field & & $72.2 \pm 2.6 \mathrm{~b}$ & $56.0 \pm 1.3 \mathrm{~b}$ & $0.3 \pm 0.0 \mathrm{~b}$ & $1.3 \pm 0.1 \mathrm{~b}$ \\
\hline \multicolumn{6}{|l|}{ Variety } \\
\hline \multicolumn{6}{|l|}{ Heirloom } \\
\hline Valencia & & $83.4 \pm 3.7 \mathrm{ab}$ & $62.6 \pm 2.2 \mathrm{a}$ & $0.4 \pm 0.1 \mathrm{~b}$ & $1.1 \pm 0.2 \mathrm{~b}$ \\
\hline \multicolumn{6}{|l|}{ Hybrid } \\
\hline BHN 589 & & $72.8 \pm 3.6 c$ & $59.5 \pm 2.1 \mathrm{ab}$ & $0.5 \pm 0.1 \mathrm{~b}$ & $1.4 \pm 0.2 \mathrm{a}$ \\
\hline Fletcher & & $65.5 \pm 2.7 \mathrm{~d}$ & $55.5 \pm 2.0 \mathrm{c}$ & $0.4 \pm 0.1 \mathrm{~b}$ & $1.4 \pm 0.2 \mathrm{a}$ \\
\hline Primo Red & & $66.6 \pm 3.4 \mathrm{~d}$ & $57.0 \pm 1.6 \mathrm{bc}$ & $0.8 \pm 0.1 \mathrm{a}$ & $1.6 \pm 0.2 \mathrm{a}$ \\
\hline \multicolumn{6}{|l|}{ Planting date ${ }^{\mathrm{w}}$} \\
\hline Factor & df & & & $P>\mathrm{F}$ & \\
\hline $\begin{array}{l}\text { Production system (PS) } \\
\text { P }\end{array}$ & 1 & $<0.0001$ & $<0.0001$ & $<0.0001$ & 0.0105 \\
\hline Variety (VAR) & 5 & $<0.0001$ & $<0.0001$ & $<0.0001$ & $<0.0001$ \\
\hline Planting date (PD) & 2 & $<0.0001$ & 0.0002 & 0.1532 & $<0.0001$ \\
\hline $\mathrm{PS} \times \mathrm{VAR}$ & 5 & 0.1034 & 0.3576 & 0.0037 & 0.1568 \\
\hline $\mathrm{PS} \times \mathrm{PD}$ & 2 & 0.0846 & 0.8915 & 0.0177 & $<0.0001$ \\
\hline $\mathrm{VAR} \times \mathrm{PD}$ & 10 & 0.2633 & 0.6628 & 0.1363 & 0.0193 \\
\hline $\mathrm{PS} \times \mathrm{VAR} \times \mathrm{PD}$ & 10 & 0.8791 & 0.2299 & 0.1406 & 0.7681 \\
\hline
\end{tabular}

"Plant height taken 6 weeks after transplanting; $1 \mathrm{~cm}=0.3937$ inch.

${ }^{y}$ Complete inflorescence is four to six flowers (only counted in 2010); incomplete inflorescence is three or fewer flowers (only counted in 2010).

'Mean separation by Tukey's honestly significant difference test at $P \leq 0.05$.

wPlanting dates were 27 Mar., 17 Apr., and 8 May 2009; and 25 Mar., 16 Apr., and 7 May 2010. 
Schafer Fisheries, Thomson, IL) administered through a fertilizer injector (Dosatron International, Clearwater, FL). Fertilizer application rate was increased to 0.8 gal per week during fruiting. Plants in the open field plots were protected from frost until after the average frost free date for Knoxville, TN (15 Apr.) with frost blankets $[50 \%$ light transmittance (Agribon Ag-50; Polymer Group, Charlotte, NC)]. The fabric was pulled over the wire hoops and anchored to the ground with landscape staples. When nighttime temperatures were above $50^{\circ} \mathrm{F}$ (around 1 May for both years), the fabric covers were removed from the open field plots, and the high tunnel sides and end walls were opened for the duration of the season. Tomato plants in 2009 were pruned to two main stems and clipped to trellis line supported by 8 - $\mathrm{ft}$ metal posts. In 2010 , the plants were pruned the same way, and a Florida weave training system was used with two plants twined between 7 -ft wooden stakes.

TOMATO PLANT GROWTH, YIELD, AND GRADE. To determine differences in growth and flowering between plants grown in tunnels and outside plots, plant height was recorded on three plants per plot 7 weeks after transplanting (WAT) in 2009 and 6 WAT in 2010. Fruit and flower cluster number were also measured at the same time in 2010. A "complete" inflorescence was considered four to six flowers or fruit, and an "incomplete" inflorescence was one to three flowers or fruit.

Harvest began for plots from the first planting date (27 Mar.) on 24 June 2009. Harvesting began for plots from the second planting date (17 Apr.) on 2 July and the third planting date (7 May) on 16 July (Table 1). Fruit were harvested twice per week for all planting dates until 8 Aug. 2009 when production declined. In 2010 , harvesting began on the first planting date on 17 June, the second planting date on 25 June, and the third planting date on 15 July. Harvesting continued until 9 Aug. 2010 when production declined. Tomato fruit were graded according to marketability and size. Marketable and unmarketable fruit number and weight were recorded per plot. Marketable fruit were graded to Florida size standards, where tomatoes measuring 3-15/32 to $4-6 / 8$ inches $(4 \times 5$ to $3 \times 4)$ in diameter were considered "jumbo"; $2-28 / 32$ to $3-15 / 32$ inches $(5 \times 6)$ "extra-large"; $2-17 / 32$ to $2-28 / 32$ inches $(6 \times 6)$ "large" and $2-9 / 32$ to $2-17 / 32$ inches $(6 \times 7)$ "medium." Unmarketable fruit were classified according to early blight symptoms, physiological disorders (blossom end rot, cracks, catfacing, or sunscald), and other imperfections, including splits, insect damage, bruises, or insufficient size. Tomatoes measuring $6.5 \mathrm{~cm}$ in diameter or less were considered too small for commercial use and not included in marketable yields.

Disease Rating. Plots were rated for early blight on 26 June, 17 July, and 5 Aug. 2009 (three dates total) and weekly in 2010 , beginning on 26 May and ending on 4 Aug. (11 dates total). In 2010, plants were sprayed with copper hydroxide [77\% a.i. (Champ WG; Nufarm Americas, Burr Ridge, IL)] at the label rate of $2.3 \mathrm{lb} /$ acre a.i.,

Table 3. Marketable and total fruit weight, total fruit number, and average fruit weight of six varieties of organically grown tomato plants over three planting dates in high tunnels and open-field plots in 2009 at the University of Tennessee Organic Crops Unit in Knoxville, TN.

\begin{tabular}{|c|c|c|c|c|c|c|}
\hline Treatment & & $\begin{array}{c}\text { Marketable fruit } \\
\text { wt }(\mathrm{kg} / \text { plant })^{\mathrm{z}}\end{array}$ & $\begin{array}{c}\text { Total fruit } \\
\text { wt (kg/plant) }\end{array}$ & $\begin{array}{l}\text { Marketable fruit } \\
\text { (no./plant) }\end{array}$ & $\begin{array}{l}\text { Total fruit } \\
\text { (no./plant) }\end{array}$ & $\begin{array}{c}\text { Avg fruit } \\
\text { wt (kg/fruit) }\end{array}$ \\
\hline \multicolumn{7}{|l|}{ Production system } \\
\hline High tunnel & & 2.1 & 6.1 & $12.7 \mathrm{a}^{\mathrm{y}}$ & 23.2 & 0.3 \\
\hline Open field & & 1.3 & 4.7 & $7.9 \mathrm{~b}$ & 18.7 & 0.3 \\
\hline \multicolumn{7}{|l|}{ Variety } \\
\hline \multicolumn{7}{|l|}{ Heirloom } \\
\hline Valencia & & $1.7 \mathrm{a}$ & 5.6 & $10.1 \mathrm{a}$ & $22.8 \mathrm{ab}$ & 0.3 \\
\hline \multicolumn{7}{|l|}{ Hybrid } \\
\hline BHN 589 & & $1.9 \mathrm{a}$ & 6.0 & $11.2 \mathrm{a}$ & $22.7 \mathrm{ab}$ & 0.3 \\
\hline Fletcher & & $1.9 \mathrm{a}$ & 5.4 & $12.2 \mathrm{a}$ & $20.4 \mathrm{~b}$ & 0.3 \\
\hline Primo Red & & $2.0 \mathrm{a}$ & 5.6 & $12.1 \mathrm{a}$ & $20.3 \mathrm{~b}$ & 0.3 \\
\hline \multicolumn{7}{|l|}{ Planting date } \\
\hline Factor & df & & & $P>\mathrm{F}$ & & \\
\hline Production system (PS) & 1 & 0.0921 & 0.1844 & 0.0409 & 0.1058 & 0.5569 \\
\hline Variety (VAR) & 5 & $<0.0001$ & 0.0517 & $<0.0001$ & $<0.0001$ & 0.0900 \\
\hline Planting date (PD) & 2 & 0.0099 & 0.0272 & $<0.0001$ & $<0.0001$ & 0.0037 \\
\hline $\mathrm{PS} \times \mathrm{VAR}$ & 5 & 0.0893 & 0.0443 & 0.0358 & 0.0012 & 0.7259 \\
\hline $\mathrm{PS} \times \mathrm{PD}$ & 2 & 0.5119 & 0.2890 & 0.1083 & 0.0129 & 0.8971 \\
\hline $\mathrm{VAR} \times \mathrm{PD}$ & 10 & 0.1478 & 0.0579 & 0.0809 & 0.0015 & 0.2700 \\
\hline $\mathrm{PS} \times \mathrm{VAR} \times \mathrm{PD}$ & 10 & 0.9961 & 0.9803 & 0.9924 & 0.3564 & 0.7946 \\
\hline
\end{tabular}

${ }^{\mathrm{z}} \mathrm{l} \mathrm{kg}=2.2046 \mathrm{lb}$.

${ }^{y}$ Mean separation by Tukey's honestly significant difference test at $P \leq 0.05$. 
on 3,17 , and 29 June and 14 July because of threat of late blight in the area. No fungicides were used in 2009. A Horsfall-Barratt scale was used for disease rating, with the midpoints used to calculate the area under the disease progress curve following the Shaner and Finney (1977) formula.

Temperature and precipitaTION. Outside air temperatures and precipitation were measured using a weather station (Vantage Pro 2 model 6152; Davis Instruments, Hayward, CA). High tunnel air temperatures and relative humidity were measured using a temperature/relative humidity data logger (HOBO model HI4001; Onset Computer Corp., Pocasset, MA) from 24 April to 12 Aug. 2009 and 1 April to 9 Aug. 2010. Temperature data were logged at $30-\mathrm{min}$ intervals.

Statistical analysis. Plant growth, yield, and disease data were analyzed using mixed models (PROC MIXED) analysis of variance to determine differences between production system, variety, planting date and year, as well as their interactions (SAS version 9.2; SAS Institute, Cary, NC). Tomato grade data were analyzed as percentages with mean separation done as a nonparametric rank test. Nontransformed means are reported. Plant growth, yield, and disease mean separations were done with Tukey's honestly significant difference test. Data are reported separately because of significant year by treatment interactions.

\section{Results}

TOMATO PLANT GROWTH, YIELD, AND GRADE. In 2009 and 2010, plants in the high tunnels were taller than those in the open field plots 7 and 6 WAT, respectively (Table 2 ). The growth rate between the first, second, and third planting dates was significantly different; at the same physiological age, the plants were tallest in the May planting date, followed by the April and March. Additionally, there was a difference in plant height between varieties. As expected, heirloom plants, with an indeterminate growth habit, were taller than hybrid plants with a determinate growth habit.
In 2009 , complete and incomplete inflorescences were counted at $13 \mathrm{WAT}$, and there were higher numbers of both complete and incomplete inflorescences in the high tunnels vs. open field plots, and there were no differences in the number of complete inflorescences by planting date; however, the May planting date had more incomplete inflorescences than the March and April dates (Table 2). There were also differences among varieties, with 'Primo Red' having the fewest incomplete inflorescences. These data are not shown because the flower counts were done relatively late in the season in 2009 and the overall flower counts were low at 13 WAT.

In 2010, complete and incomplete inflorescences were counted at 6 WAT. There were more complete and incomplete inflorescences in the high tunnels than in the open field plots (Table 2). There were no differences in complete inflorescences between planting dates; however, there were more incomplete inflorescences in plots from the third planting date than in the first or second. 'Arkansas Traveler'

Table 4. Marketable and total fruit weight, total fruit number, and average fruit weight of six varieties of organically grown tomato plants over three planting dates in high tunnels and open-field plots in 2010 at the University of Tennessee Organic Crops Unit in Knoxville, TN.

\begin{tabular}{|c|c|c|c|c|c|c|}
\hline Treatment & & $\begin{array}{l}\text { Marketable fruit wt } \\
(\mathrm{kg} / \text { plant })^{\mathrm{z}}\end{array}$ & $\begin{array}{l}\text { Total fruit wt } \\
\text { (kg/plant) }\end{array}$ & $\begin{array}{c}\text { Marketable fruit } \\
\text { (no./plant) }\end{array}$ & $\begin{array}{l}\text { Total fruit } \\
\text { (no./plant) }\end{array}$ & $\begin{array}{l}\text { Avg fruit wt } \\
\text { (kg/fruit) }\end{array}$ \\
\hline \multicolumn{7}{|l|}{ Production system } \\
\hline High tunnel & & 2.4 & 4.9 & $10.2 \mathrm{a}^{\mathrm{y}}$ & 28.7 & 0.2 \\
\hline Open field & & 2.0 & 5.3 & $8.5 \mathrm{~b}$ & 27.5 & 0.2 \\
\hline \multicolumn{7}{|l|}{ Variety } \\
\hline \multicolumn{7}{|l|}{ Heirloom } \\
\hline Valencia & & $1.7 \mathrm{c}$ & $3.9 \mathrm{c}$ & $7.7 \mathrm{c}$ & $27.2 \mathrm{~b}$ & $0.1 \mathrm{c}$ \\
\hline \multicolumn{7}{|l|}{ Hybrid } \\
\hline BHN 589 & & $2.7 \mathrm{~b}$ & $6.2 \mathrm{ab}$ & $11.7 \mathrm{~b}$ & $32.0 \mathrm{a}$ & $0.2 \mathrm{~b}$ \\
\hline Fletcher & & $2.7 \mathrm{~b}$ & $5.6 \mathrm{~b}$ & $11.4 \mathrm{~b}$ & $28.2 \mathrm{ab}$ & $0.2 \mathrm{~b}$ \\
\hline Primo Red & & $3.3 \mathrm{a}$ & $6.5 \mathrm{a}$ & $13.7 \mathrm{a}$ & $31.8 \mathrm{a}$ & $0.2 \mathrm{~b}$ \\
\hline \multicolumn{7}{|l|}{ Planting date } \\
\hline Factor & df & & & $P>\mathrm{F}$ & & \\
\hline Production system (PS) & 1 & 0.1492 & 0.3150 & 0.0420 & 0.1976 & 0.0553 \\
\hline Variety (VAR) & 5 & $<0.0001$ & $<0.0001$ & $<0.0001$ & $<0.0001$ & $<0.0001$ \\
\hline Planting date (PD) & 2 & $<0.0001$ & 0.0025 & $<0.0001$ & $<0.0001$ & 0.3459 \\
\hline $\mathrm{PS} \times \mathrm{VAR}$ & 5 & 0.0359 & 0.3724 & 0.0183 & 0.0785 & 0.7596 \\
\hline $\mathrm{PS} \times \mathrm{PD}$ & 2 & 0.9114 & 0.9868 & 0.9416 & 0.2458 & 0.7596 \\
\hline $\mathrm{VAR} \times \mathrm{PD}$ & 10 & 0.0002 & 0.0091 & 0.0006 & $<0.0001$ & 0.1835 \\
\hline $\mathrm{PS} \times \mathrm{VAR} \times \mathrm{PD}$ & 10 & 0.0785 & 0.4259 & 0.1801 & 0.1975 & 0.0101 \\
\hline
\end{tabular}

${ }^{\mathrm{z}} \mathrm{l} \mathrm{kg}=2.2046 \mathrm{lb}$

${ }^{y}$ Mean separation by Tukey's honestly significant difference test at $P \leq 0.05$. 
had the fewest complete inflorescences and 'Cherokee Purple' and 'Primo Red' had the most. 'Arkansas Traveler' and 'Valencia' had the fewest incomplete inflorescences.

There were differences in the number of marketable fruit per plant by production system in both 2009 (Table 3) and 2010 (Table 4). More total fruit were harvested from the high tunnel plots in both years, but fruit weight was unaffected by production system. Marketable yield differed by variety in both years. In 2009, 'Cherokee Purple' had fewer marketable and total fruit per plant than the other varieties (Table 3 ). In 2010 , hybrid varieties produced more marketable and total fruit than heirloom varieties (Table 4 ). In both years, more marketable and total fruit were harvested from the March planting date, followed by April and May, on both a sub-sub-plot and per plant basis (Tables 3 and 4 ). A variety $\times$ planting date interaction for total fruit per plant in 2009 and total and marketable fruit and fruit weight per plant in 2010 showed that in general, yields were greatest for March plots, followed by April and May (Figs. 1 and 2); however, for 'Primo Red', marketable and total fruit (per plant) was higher in April plots, followed by March and lastly May. The harvest window was longer for March planted tomato, followed by April and May, respectively, and the days after planting to peak fruit harvest were roughly $2-3$ weeks longer for plots planted in March than in April, as shown in Table 1.

In 2009, a higher proportion of extra-large fruit were harvested from open field plots than in the high tunnels, and the inverse was true for large fruit (Table 5). High tunnels did not affect size distribution in 2010 . Size was influenced by variety, with 'Cherokee Purple' having the most jumbo fruit in both years. Planting date also had an effect, with the March planting date having a higher proportion of jumbo fruit in both years. In both years, a higher proportion of

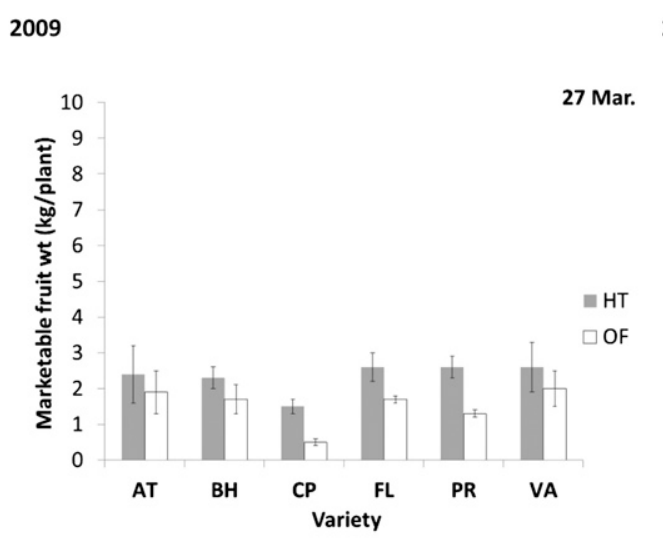

2010
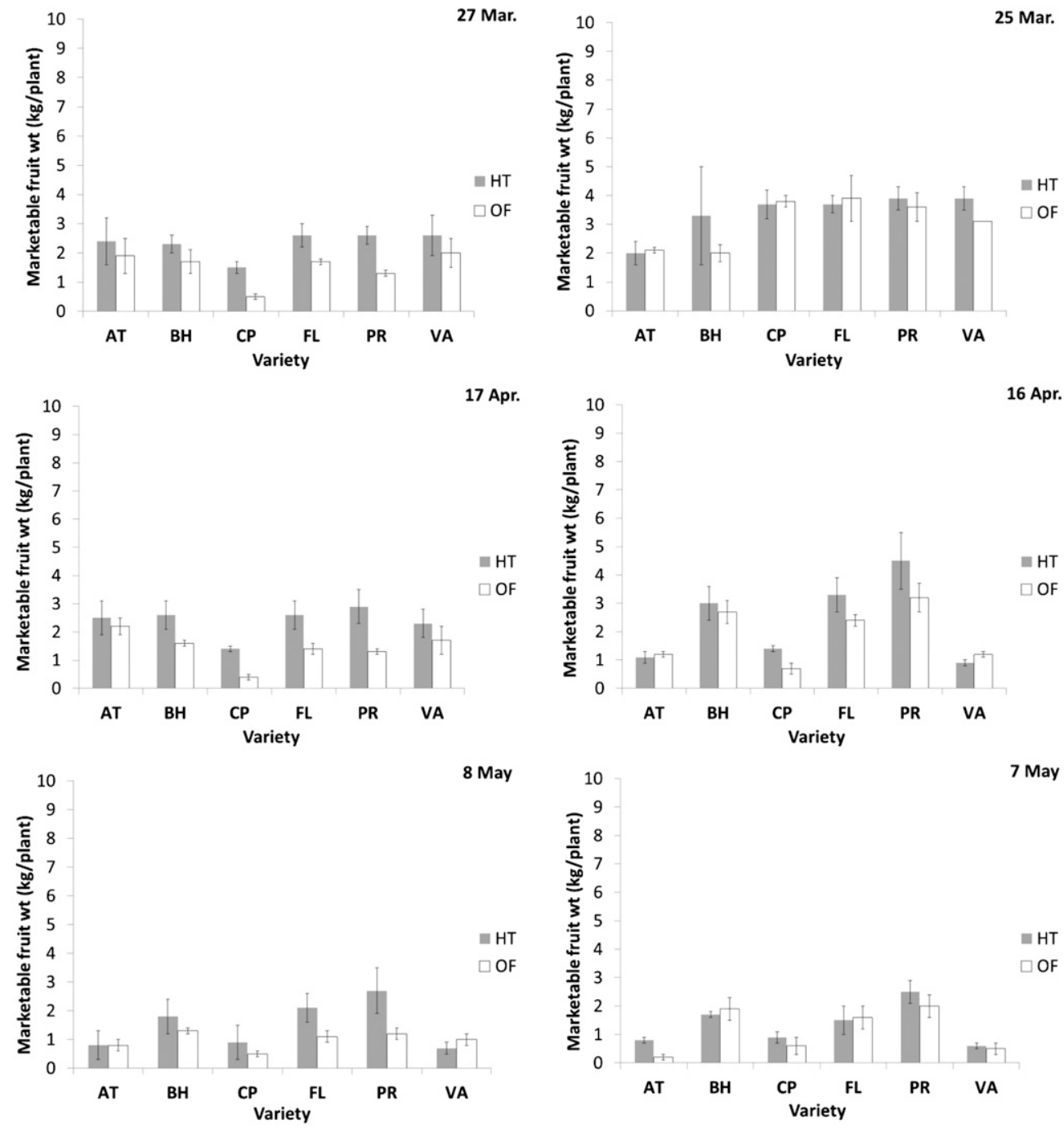

Fig. 1. Marketable fruit weight (mean \pm SE) of six varieties of organically grown tomato plants ['Arkansas Traveler' (AT), 'BHN 589' (BH), 'Cherokee Purple' (CP), 'Fletcher' (FL), 'Primo Red' (PR), and 'Valencia' (VA)] over three planting dates (March, April, and May) in high tunnels (HT) and open-field plots (OF) in 2009 and 2010 at the University of Tennessee Organic Crops Unit in Knoxville, TN; $1 \mathrm{~kg}=2.2046 \mathrm{lb}$. 

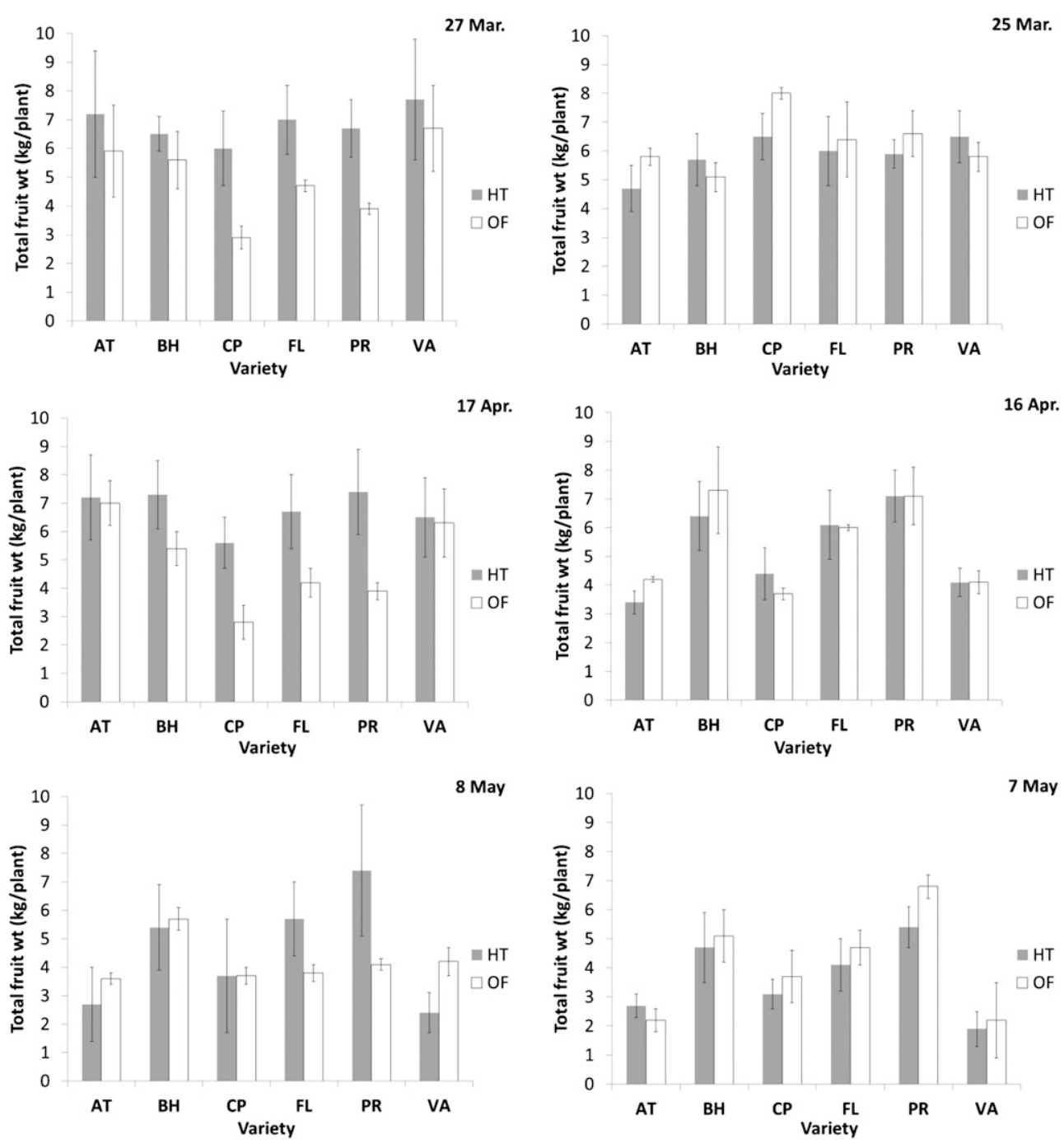

Fig. 2. Total fruit weight (mean \pm SE) of six varieties of organically grown tomato plants ['Arkansas Traveler' (AT), 'BHN 589' (BH), 'Cherokee Purple' (CP), 'Fletcher' (FL), 'Primo Red' (PR), and 'Valencia' (VA)] over three planting dates (March, April, and May) in high tunnels (HT) and open field plots (OF) in 2009 and 2010 at the University of Tennessee Organic Crops Unit in Knoxville, $\mathrm{TN} ; 1 \mathrm{~kg}=2.2046 \mathrm{lb}$.

extra-large and large fruit were harvested than jumbo and medium shown in Table 5 .

Disease Rating. Because of year by treatment interactions, early blight severity was analyzed separately by year (Table 6). Overall, in both years, severity of early blight was significantly less on plants in the high tunnels than plants in the open field plots (Fig. 3). In 2009 and 2010 , disease progression was more severe on the first planting date of tomato, followed by the second and third planting dates, respectively.

Temperature and PRecipitaTION. Temperatures were warmer in 2010 than in 2009 , reaching above
$86{ }^{\circ} \mathrm{F}$ as shown in Fig. $4 \mathrm{~A}$ and $\mathrm{B}$. Despite having side and end walls open, the average high temperatures in the high tunnels reached above $100{ }^{\circ} \mathrm{F}$ during midday in both years. The highest temperature recorded on a single day in the high tunnels was $125^{\circ} \mathrm{F}$ in mid-July 2010. The mean temperature range from April to Aug. 2009 was $51-75{ }^{\circ} \mathrm{F}$ in open field plots, a difference of $24^{\circ} \mathrm{F}$; however, the mean temperature range during the same period in the high tunnels was $72-81^{\circ} \mathrm{F}$, a difference of $9^{\circ} \mathrm{F}$. This trend was the same in 2010 (Fig. $4 \mathrm{~A}$ and $\mathrm{B})$. The high tunnels did not retain much heat into the evening hours, where average low temperatures were not different from open field plots.

Precipitation was greater in 2009 (27.8 inches) than in 2010 (17.1 inches). May and July were the wettest months in both years (Fig. 5), with 6.8 and 7.7 inches reported in 2009 , respectively, and 4.3 and 4.2 inches reported in 2010. The difference in rainfall between years was greatest for May, June, and July (Fig. 5).

\section{Discussion}

Greater marketable yields by weight per plant were harvested from the high tunnels than the open field plots in both years. However, yields in both years were low under the $11 \mathrm{~kg}$ 
Table 5. Size classes (grades) of six varieties of tomatoes from organically grown tomato plants over three planting dates in high tunnels and open-field plots in 2009 and 2010 at the University of Tennessee Organic Crops Unit in Knoxville, TN.

\begin{tabular}{|c|c|c|c|c|c|c|c|c|}
\hline \multirow[b]{3}{*}{ Treatment } & \multicolumn{8}{|c|}{ Marketable fruit by size class $(\%)^{\mathrm{z}}$} \\
\hline & \multicolumn{4}{|c|}{2009} & \multicolumn{4}{|c|}{2010} \\
\hline & Jumbo & Extra-large & Large & Medium & Jumbo & Extra-large & Large & Medium \\
\hline High tunnel & 4 & $21 b^{y}$ & $45 \mathrm{a}$ & 29 & 5 & 36 & 33 & 26 \\
\hline Open field & 5 & $28 \mathrm{a}$ & $41 \mathrm{~b}$ & 26 & 5 & 38 & 32 & 25 \\
\hline \multicolumn{9}{|l|}{ Variety } \\
\hline Cherokee Purple & $10 \mathrm{a}$ & $52 \mathrm{a}$ & $31 \mathrm{c}$ & $7 \mathrm{~d}$ & $11 \mathrm{a}$ & 49 a & 26 & $15 \mathrm{c}$ \\
\hline Valencia & $2 \mathrm{~cd}$ & $12 \mathrm{c}$ & $49 \mathrm{ab}$ & $37 \mathrm{~b}$ & $2 \mathrm{~b}$ & $23 \mathrm{~b}$ & 38 & 38 a \\
\hline \multicolumn{9}{|l|}{ Hybrid } \\
\hline BHN 589 & $5 \mathrm{ab}$ & $26 \mathrm{~b}$ & $45 \mathrm{~b}$ & $25 \mathrm{c}$ & $3 \mathrm{~b}$ & 38 a & 33 & $25 \mathrm{~b}$ \\
\hline Fletcher & $3 \mathrm{bc}$ & $20 \mathrm{~b}$ & $50 \mathrm{a}$ & $27 \mathrm{c}$ & $4 \mathrm{~b}$ & 39 a & 34 & $23 \mathrm{~b}$ \\
\hline May & $2 c$ & $23 \mathrm{~b}$ & $48 \mathrm{a}$ & 27 & $1 \mathrm{c}$ & $39 a$ & 34 & $26 \mathrm{~b}$ \\
\hline
\end{tabular}

\begin{tabular}{|c|c|c|c|c|c|c|c|c|c|}
\hline Factor & df & & & & $P$ & & & & \\
\hline Production system (PS) & 1 & 0.8722 & 0.0001 & 0.0312 & 0.0848 & 0.9757 & 0.6505 & 0.4871 & 0.4414 \\
\hline Variety (VAR) & 5 & $<0.0001$ & $<0.0001$ & $<0.0001$ & $<0.0001$ & 0.0005 & $<0.0001$ & 0.0710 & $<0.0001$ \\
\hline Planting date (PD) & 2 & $<0.0001$ & 0.1400 & $<0.0001$ & 0.1609 & $<0.0001$ & 0.0001 & 0.3257 & 0.0029 \\
\hline $\mathrm{PS} \times \mathrm{PD}$ & 2 & 0.1081 & 0.0225 & 0.0246 & 0.4611 & 0.9599 & 0.4483 & 0.8631 & 0.5242 \\
\hline $\mathrm{VAR} \times \mathrm{PD}$ & 10 & 0.3839 & 0.9123 & 0.5934 & 0.7598 & 0.0499 & 0.1069 & 0.3189 & 0.0811 \\
\hline $\mathrm{PS} \times \mathrm{VAR} \times \mathrm{PD}$ & 10 & 0.8956 & 0.6662 & 0.3726 & 0.7292 & 0.7305 & 0.1552 & 0.1473 & 0.1710 \\
\hline
\end{tabular}

${ }^{\mathrm{z} J u m b o}=3-15 / 32$ to $4-6 / 8$ inches, extra-large $=2-28 / 32$ to $3-15 / 32$ inches, large $2-17 / 32$ to $2-28 / 32$ inches, $\mathrm{medium}=2-9 / 32$ to $2-17 / 32$ inches; 1 inch $=2.54 \mathrm{~cm}$. ${ }^{y}$ Mean separation of transformed ranks for non-parametric data by Tukey's honestly significant difference test at $P \leq 0.05$. Non-transformed means for each size class are reported.

xPlanting dates were 27 Mar., 17 Apr., and 8 May 2009; and 25 Mar., 16 Apr., and 7 May 2010.

Table 6. Interaction of production system, variety and planting date on area under the disease progress curve (AUDPC) of early blight on six varieties of organically grown tomato plants ('Arkansas Traveler', 'BHN 589', 'Cherokee Purple', 'Fletcher', 'Primo Red', and 'Valencia') over three planting dates (March, April, and May) in high tunnels and open-field plots in 2009 and 2010 at the University of Tennessee Organic Crops Unit in Knoxville, TN.

\begin{tabular}{lrrr}
\hline & & \multicolumn{2}{c}{ Early blight AUDPC } \\
\cline { 3 - 4 } & & $\mathbf{2 0 0 9 ^ { \mathrm { z } }}$ & $\mathbf{2 0 1}^{\mathrm{y}}$ \\
\cline { 3 - 4 } Factor & df & 0.0059 & $\mathbf{P} \mathbf{F}$ \\
\hline Production system (PS) & 1 & 0.0054 & 0.0191 \\
Variety (VAR) & 5 & $<0.0001$ & $<0.0001$ \\
Planting date (PD) & 2 & 0.0147 & $<0.0001$ \\
PS $\times$ VAR & 5 & 0.0140 & 0.0002 \\
PS $\times$ PD & 2 & 0.8868 & $<0.0001$ \\
VAR $\times$ PD & 10 & 0.5990 & 0.0001 \\
PS $\times$ VAR $\times$ PD & 10 & & 0.0011 \\
\hline
\end{tabular}

${ }^{2}$ Dates sampled: 26 June, 17 July, and 5 Aug. 2009.

'Dates sampled: 26 May, 2 June, 10 June, 18 June, 24 June, 1 July, 7 July, 14 July, 21 July, 28 July, and 4 Aug. 2010.

per plant optimum for high tunnel production (Jett, 2010). The low yields may have been due to heat stress, which can affect pollen release and germination when temperatures are consistently high. Sato et al. (2000) have shown that when tomato is grown under a high-temperature regime $\left(90 / 79{ }^{\circ} \mathrm{F}\right.$ day/night $)$, fewer fruit were set because of production and release of fewer pollen grains. Sugiyama et al. (1996) have shown that tomato flowers may drop under high heat conditions. Our data show that high tunnels retained more heat during the day than the open field plots, with temperatures reaching as high as $125^{\circ} \mathrm{F}$ in midday, even with doors open and sides rolled up for ventilation, which likely could have caused heat stress. High tunnels can keep temperatures $10-15^{\circ} \mathrm{F}$ warmer in the spring, which is an advantage over open field plots. However, in midsummer, temperatures can be $30^{\circ} \mathrm{F}$ warmer than the open field, suggesting that in our area, special efforts should be made to increase ventilation and cooling in high tunnels.

Lower yields may also be due to lower soil $\mathrm{N}$ availability, as was reported in a California study (Scow et al., 1994). Lower soil $\mathrm{N}$ content is a common challenge when transitioning from conventional to organic production as soil organic matter and soil microbial biomass can take years to increase, which may explain our lower than expected yields. Irrigation can 

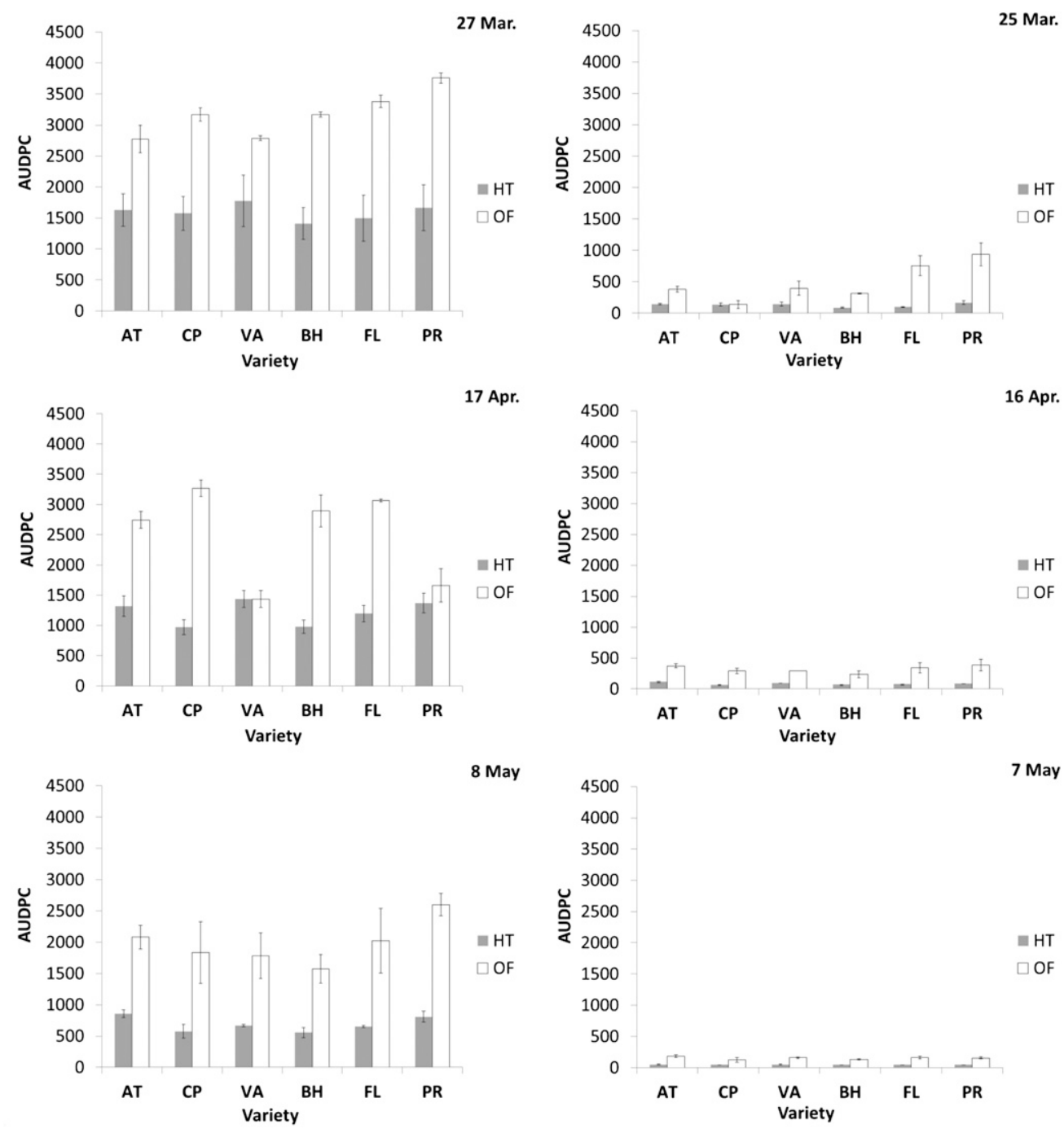

Fig. 3. Area under the disease progress curve [AUDPC (mean \pm SE)] of early blight on six varieties of organically grown tomato plants ['Arkansas Traveler' (AT), 'BHN 589' (BH), 'Cherokee Purple' (CP), 'Fletcher' (FL), 'Primo Red' (PR), and 'Valencia' (VA) ] over three planting dates (March, April, and May) in high tunnels (HT) and open field plots (OF) in 2009 and 2010 at the University of Tennessee Organic Crops Unit in Knoxville, TN.

also affect size, number, and weight of fruit produced, as well as quality of the fruit. In a study by Pulupol et al. (1996), glasshouse tomato plants grown under a water deficit showed reduced yields, but higher soluble sugars and color intensity. Excess irrigation can cause vine-ripened tomatoes in the open field to split before harvest, and high tunnels can help manage this. We did not observe differences in total fruit number (per plant), or weight (on a per- plant or fruit basis) between the tunnels and the open field plots, indicating that differences in irrigation between production systems were not a factor in our study.
This study confirms that growing tomato in high tunnels can decrease severity of early blight early in the season. Our results are similar to Baysal et al. (2009), who found that early blight incidence and severity were lower on tomato plants grown organically in high tunnels, and disease incidence was lessened further with the addition of compost. Spores of $A$. solani are dispersed via rain splash; thus, limiting splash dispersal by incorporating mulches or protected culture can significantly reduce the incidence of disease (Mills et al., 2002). In our study, early blight severity was greater in 2009 than in 2010. This may be due to more rainfall in 2009 and the use of a copper sulfate protectant in 2010, which was warranted because of the extreme threat of late blight in our area. Although early blight severity was greater for March-planted tomato in both years, yields were unaffected. Early blight can reduce marketability of tomato fruit, in which it causes concentric rings, cracking, and sunken lesions. 'Primo Red' was the variety most impacted by early blight in both years, while 'BHN 589' was least affected.

Planting date influenced tomato yields, marketability, disease progression, as well as plant growth rate and production of inflorescences. Plants from the first and second planting dates produced more total fruit weight 
(A)

2009

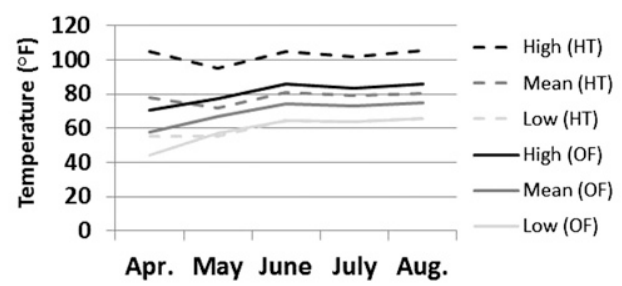

(B)

2010

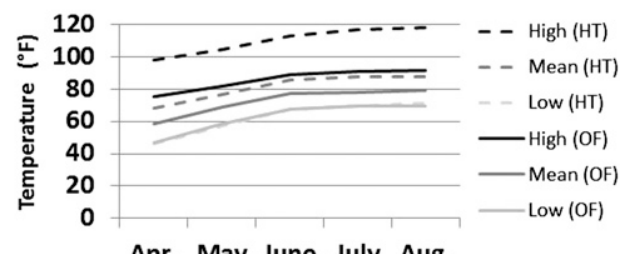

Apr. May June July Aug.

Fig. 4. Average open field (OF) and high tunnel (HT) temperatures from April to Aug. 2009 (A) and 2010 (B) at the University of Tennessee Organic Crops Unit in Knoxville, TN; $\left({ }^{\circ} \mathrm{F}-32\right) \div 1.8={ }^{\circ} \mathrm{C}$.

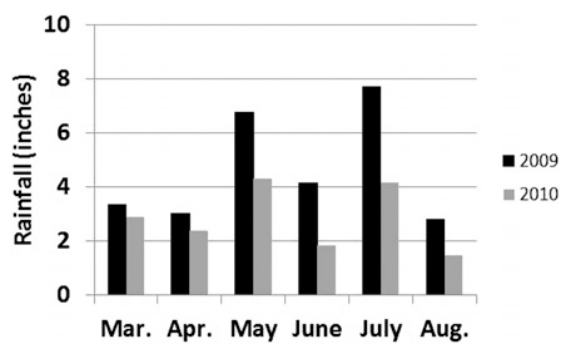

Fig. 5. Average monthly rainfall from March to Aug. 2009 and 2010 at the University of Tennessee Organic Crops Unit in Knoxville, $T N$; 1 inch $=2.54 \mathrm{~cm}$.

per plant and more marketable fruit throughout the season than those from the third planting date. This could be due to the longer harvest window of the earlier planted tomato and flowering and fruit set occurring before extreme heat. The March planted plots took longer to develop and reach peak harvest than the May planted plots, but also produced more fruit. Differences in yield because of planting date could be influenced by higher temperatures and heat stress at initial flowering during the third planting date, which would inhibit pollination, as discussed above. This is contrasting to a study comparing early planting dates of tomato grown in high tunnels in Connecticut that showed that early planting (3 Apr.) had fewer, smaller fruit than the later planting dates (17 April and 1 May), and this was attributed to cooler soil temperatures that inhibited uptake of $\mathrm{N}$ and magnesium early in the season (Gent, 1992). Although soil temperature was not measured in this study, yield was not decreased in our early ( 25 and 27 Mar.) planting dates in Tennessee.

Early blight is primarily a disease of older leaf tissue, and symptoms first become apparent on the lower leaves before progressing to the plant canopy. Earlier planting dates allow for advanced progression of early blight in tomato, and we did not find that early blight affected yields in the third planting date. Plants in the third planting date were taller than those planted earlier at 6 WAT. These plants also had lower yields. This suggests that the plants put more energy into vegetative production than into fruiting, possibly as a response to increased temperatures at the time of initial flowering. Research has shown that the conditions that favor stem elongation are daytime $(8 \mathrm{~h})$ temperatures of $79^{\circ} \mathrm{F}$ and nighttime $(16 \mathrm{~h})$ temperatures of $68^{\circ} \mathrm{F}$ (Leonard, 1962), conditions that were present a few weeks after the May plants were planted. Despite increased disease progression, our data show that earlier planting dates can lead to increased productivity on a per-plant basis. These gains have implications for growers as producers can maximize yield by planting earlier in the season.
Heirloom varieties produced less marketable fruit, both in number and weight, than hybrid varieties in both high tunnels and open field plots in 2010 . This is not atypical of heirloom plants compared with hybrids, as hybrid tomato varieties are bred for consistency and productivity, where heirloom varieties are prized for their distinctive quality attributes (Bai and Lindhout, 2007; Vavrina et al., 1997). Fruit from hybrid tomato plants tended to be more consistent in grade than heirloom fruit, with higher proportions of jumbo, extra-large and large fruit, and fewer medium sized fruit. Although growers are attracted to consistency, heirloom varieties are becoming more popular at farmers markets and some consumers will pay more for them (Wise, 2005), which can offset the economics of yield difference. In 2009, a higher percentage of heirloom tomato fruit grown in high tunnels were marketable compared with those grown in the open field; however, this did not hold true in 2010. Yield disparities are most likely due to the use of copper sulfate as a fungicide in 2010, which increased the quality of heirloom tomato plants grown in the open field by reducing disease, and to the increased plant spacing and improved trellising, which provided better air circulation within the plant canopy.

This study shows that organic tomato growers can use high tunnels to extend their growing season, reduce plant defoliation by early blight, and produce larger and more marketable fruit when compared with fieldgrown fruit. High tunnels have the potential to help regulate plant water uptake, thereby, reducing fruit splitting and cracking that is commonly observed among heirloom tomato varieties. However, daytime temperatures in the tunnels can be extremely high in eastern Tennessee and result in plant heat stress. Efforts should be taken to increase ventilation of high tunnels, and planting time should be optimized so that tomato plants are finished producing before the height of summer. It may be possible to plant tomato seedlings in high tunnels in eastern Tennessee in early March or late February as long as soil temperatures are at least $54{ }^{\circ} \mathrm{F}$ (Gent, 1992). Even in open field plots, the earlier planted tomato yielded more marketable fruit during the production 
season when compared with yields from the later planted tomato, until early blight became severe. Organically grown tomato yields may be lower than those grown conventionally; however, these differences tend to equalize over the long term (Poudel et al., 2002). Additionally, price premiums for organically grown tomatoes may offset the reduced yield (Clark et al., 1998) making organic production a viable economic option for growers.

\section{Literature cited}

Bai, Y. and P. Lindhout. 2007. Domestication and breeding of tomatoes: What have we gained and what can we gain in the future? Ann. Bot. (Lond.) 100:10851094.

Baysal, F., B. McSpadden-Gardener, J. Cardina, M. Kleinhenz, and S. Miller. 2009. Effect of transition strategy and production system on disease development in organic tomatoes. Acta Hort. 808:113-116.

Clark, M.S., H. Ferris, K. Klonsky, W.T. Lanini, A.H.C. van Bruggen, and F.G. Zalom. 1998. Agronomic, economic, and environmental comparison of pest management in conventional and alternative tomato and corn systems in northern California. Agr. Ecosyst. Environ. 68: 51-7l.

Conner, D.S., A.D. Montri, D.N. Montri, and M.W. Hamm. 2009. Consumer demand for local produce at extended season farmers' markets: Guiding farmer marketing strategies. Renewable Agr. Food Systems 24:251-259.

Dorais, M.D.A., W. Dermers, S. Van lepern, and A.P. Papadopoulos. 2004. Greenhouse tomato fruit cuticle cracking. Hort. Rev. 30:163-184.

Emmons, C.L.W. and J.W. Scott. 1997. Environmental and physiological effects on cuticle cracking in tomato. J. Amer. Soc. Hort. Sci. 122:797-801.

Gent, M.P.N. 1992. Effect of planting date, ventilation and soil temperature on growth and nutrition of tomato in high tunnels. Plant Soil 145:81-91.

Gent, M.P.N. 2002. Growth and composition of salad greens as affected by organic compared to nitrate fertilizer and by environment in high tunnels. J. Plant Nutr. 25:981-998.
Gullino, M.L., A. Ramon, and J.C. van Lenteren. 1999. Setting the stage: Characteristics of protected cultivation and tools for sustainable crop protection. Chapter 1, p. 1-13. In: R. Albajes, M.L. Gullino, J.C. Van Lenteren, and Y. Elad (eds.). Integrated pest and disease management in greenhouse crops. Kluwer Academic Publishers, New York.

Jett, L.W. 2010. Production of tomatoes within a high tunnel. 4 Apr. 2011. <http:// www.hightunnels.org/ForGrowers/ WarmSeasonVegetables/warmseason vegtomprod.htm>.

Jordan, J.A. 2007. The heirloom tomato as a cultural object. Sociol. Ruralis 47: 20-41.

Kennedy, G.G., L.R. Romanow, S.F. Jenkins, and D.C. Sanders. 1983. Insects and diseases damaging tomato fruits in the coastal plain of North Carolina. J. Econ. Entomol. 76:168-173.

Lamont, W.J., M.D. Orzolek, E.J. Holcomb, K. Demchak, E. Burkhart, L. White, and B. Dye. 2003. Production system for horticultural crops grown in the Penn State high tunnel. HortTechnology 13:358-362.

Leonard, E.R. 1962. Inter-relations of vegetative and reproductive growth, with special reference to indeterminate plants. Bot. Rev. 28:354-410.

Millner, P., S. Reynolds, X. Nou, and D. Krizek. 2009. High tunnel and organic horticulture: Compost, food safety, and crop quality. HortScience 44:242-245.

Mills, D.J., C.B. Coffman, J.R. Teasdale, K.L. Everts, and J.D. Anderson. 2002. Factors associated with foliar disease of staked fresh market tomatoes grown under differing bed strategies. Plant Dis. $86: 356-361$.

Morrison, J.I.L. and D.W. Lawlor. 1999. Interactions between increasing $\mathrm{CO}_{2}$ concentration and temperature on plant growth. Plant Cell Environ. 22:659-682.

Orzolek, M.D., W.J. Lamont, and L. White. 2002. Promising horticultural crops for production in high tunnels in the mid-Atlantic area of the United States. Acta Hort. 633:453-458.

Poudel, D.D., W.R. Horwath, W.T. Lanini, S.R. Temple, and A.H.C. van Bruggen. 2002. Comparison of soil $\mathrm{N}$ availability and leaching potential, crop yields and weeds in organic, low-input and conventional farming systems in northern California. Agr. Ecosyst. Environ. 90:125-137.
Pulupol, L.U., M.H. Behboudian, and K.J. Fisher. 1996. Growth, yield, and postharvest attributes of glasshouse tomatoes produced under deficit irrigation. HortScience 31:926-929.

Raviv, M. and Y. Antignus. 2004. UV radiation effects on pathogens and insect pests of greenhouse-grown crops. Photochem. Photobiol. 79:219-226.

Sato, S., M.M. Peet, and J.F. Thomas. 2000. Physiological factors limit fruit set of tomato (Lycopersicon esculentum Mill.) under chronic, mild heat stress. Plant Cell Environ. 23:719-726.

Scow, K., O. Somasco, N. Gunapala, S. Lau, R. Venette, H. Ferris, R. Miller, and C. Shennan. 1994. Transition from conventional to low-input agriculture changes soil fertility and biology. Calif. Agr. 48:20-26.

Shaner, G. and R.E. Finney. 1977. The effect of nitrogen fertilization on the expression of slow-mildewing resistance in Knox wheat. Phytopathology 67: 1051-1056.

Sugiyama, T., S. Iwahoria, and K. Takahashi. 1996. Effect of high temperature on fruit setting of tomato under cover. Acta Hort. 4:63-69.

Vavrina, C.S., K. Armbrester, and M. Pena. 1997. Heirloom tomato cultivars. Proc. Florida State Hort. Soc. 110:391-392.

Vloutoglou, I. and S.N. Kalogerakis. 2000. Effects of inoculum concentration, wetness duration and plant age on development of early blight (Alternaria solani) and on shedding of leaves in tomato plants. Plant Pathol. 49:339-345.

Wise, S. 2005. Heirloom tomato marketing. 3 Dec. 2010 . <http://www.cals. ncsu.edu/specialty_crops/publications / reports/heirloomtomato.html>.

Wittwer, S.H. and N. Castilla. 1995. Protected cultivation of horticultural crops worldwide. HortTechnology 5: 6-23.

Zepeda, L. and D. Deal. 2009. Organic and local food consumer behaviour: $\mathrm{Al}$ phabet theory. Intl. J. Conservation Studies 33:697-705.

Zhao, X., T. Iwamoto, and E.E. Carey. 2007. Antioxidant capacity of leafy vegetables as affected by high tunnel environment, fertilisation and growth stage. J. Sci. Food Agr. 87:2692-2699. 